\title{
Improvement of creative thinking ability through problem-based learning with local culture based on students' gender and prior mathematics ability
}

\author{
Rahmi Ramadhani' ${ }^{1}$, Fajri Farid ${ }^{2}$, Fitria Lestari ${ }^{3}$, Amir Machmud \\ ${ }^{1}$ Universitas Potensi Utama, Indonesia \\ ${ }^{2}$ Department of Mathematics, Universitas Gadjah Mada, Indonesia \\ ${ }^{3}$ Department of Mathematics Education, Universitas Muhammadiyah Lampung, Indonesia \\ ${ }^{4}$ National Central University, Taiwan \\ $\triangle$ rahmiramadhani3@gmail.com
}

\section{Article Information \\ Submitted October 08, 2019 \\ Revised March 24, 2020 \\ Accepted April 27, 2020}

\section{Keywords}

Creative Thinking; Gender; Local

Culture; Prior Mathematics Ability; Problem-Based Learning.

\begin{abstract}
The purpose of this study was to determine the increase of students' creative thinking, which taught using problem-based learning with local culture (PBL-Local Culture). In this study also saw the interaction between students' gender and students' prior mathematics ability. This type of research is quasi-experiment research, using pre-test post-test control group design. Data were analyzed using SPSS 25 through Two-Way ANOVA. The result shows that increasing the creative thinking abilities of students taught using problem-based learning with local culture is significantly higher than the creative thinking abilities of students taught using classical learning. Based on the result, we found that the use of problem-based learning local culture (PBL-Local Culture) offered the opportunity to give student new experience to solving real problems in their daily life, primarily related in their local culture. Students can describe how to solve the daily life problem with mathematically modelling. This learning model has given the facility to students at the end to improve their creative thinking ability. Students make the new model of problem-solving and finally they can solve that problem with their model. This study also found that the factor of students' gender and students' prior mathematics ability has not given the effect of students' creative thinking ability. It means that there is no gap in gender and the contribution of students' prior mathematics ability in students' academic skills. Based on this study, we recommendation of this model to using in other subjects in the learning class and to improving other learning ability, not limited in creative thinking ability.
\end{abstract}

\section{INTRODUCTION}

Mathematics is one of the subjects that must be taught in the curriculum in Indonesia. Learning math is important in education because mathematics is a systematic science. Mathematics is the study of problems by finding solutions in a systematic and organized way. Language in mathematics is presented with unique symbols and characters, however the use of symbols and characters aims to understand the purpose of systematic solutions (Ramadhani, 2018). The statement was in line with that given by the National Council of Teachers Mathematics (Gordah \& Astuti, 2013) where one of the goals of mathematics learning is to learn to solve problems (mathematical problem solving). In addition to the NCTM statement, application of mathematics must be able to integrated and support the learning system in schools, one of which is in developing curriculum in 2013 which is implemented in Indonesian schools (Abdurrahman et al., 2020). In the 2013 curriculum (Azis, 2012), one of the important mathematical ability in learning in school is creative thinking ability. Creative thinking ability needed to master and 
create the technologies of the future, which means that mathematics needs to be given to all students ranging from elementary schools to colleges to equip the students in the ability of logical, analytical, systematic, critical, creative and ability to cooperate. In line with the statement, Nur'aeni (2008) also said that creativity is essential in human life, he needed to overcome the difficulties, find a way out of all the complications, breaking the stagnation and to achieve desirable goals. Without creativity, a person will often hit a deadlock, and it inhibits even will reduce the spirit of achievement.

Based on the explanation above, it is concluded that mathematics is essential for student learning in school. However, it is inversely proportional to the facts obtained from TIMSS 2007, TIMSS 2011 and PISA 2009 that the Indonesian students can answer math questions in a low international standard (Ramadhani, 2018), the results were not many different studies were also obtained from Hans Jellen of the University of Utah, the United States and Klaus Urban of the University of Hannover, Germany. They obtain the result that from the eight countries studied, children's creativity lowest Indonesia (Rahman, 2012), he continued that the lack of ability to think creatively impact on the low achievement of students. One of the causes of low ability students creative thinking is a learning process in schools is less than optimal. Teachers are more dominant than students in explaining the material while students just being recipients of the information. As a result, students were solely concerned with steps to resolve given by the teacher. The reason of that is the student has no other alternative ability to solve problems, and students ultimately lack the ability good flexibility, while the flexibility is one important component in the ability to think creatively (Munandar, 2009).

That is because the focus of the learning that has been applied tend to use conventional learning models. In classical learning, students tend to be passive and not free to be creative in learning the teaching materials to solving mathematical problems. The application of models of student-centered learning (student-centered learning) needs to improve the ability of students to be creative in the learning process. The learning model student-centred curriculum is also offered in 2013 to be applied in the classroom. One is a model of problem-based learning. Problem-based learning focused on the real issues that non-routine. It is expected to help the students to be creative when solving real problems. Ramadhani \& Narpila (2018) Characterized by problem-based learning students work with each other. They cooperate to motivate to continuously engage in complex tasks and increase opportunities for shared inquiry and dialogue to develop social skills think (Ramadhani, 2016).

The application of problem-based learning in improving the ability of creative thinking will be more effective if it is integrated with the local culture. Frudental (Van den HeuvelPanhuizen, 1996) stating that mathematics should be linked with the existing realities, remain close to the students and relevant to society. This perspective involves mathematics not only as a subject but as a human activity, which is very close to the local culture. The same opinion was also expressed by Bishop (Tandailing, 2013) that mathematics is a part of the culture, which has integration in all aspects of human life. Thus, the mathematics for a person will have an impact on the person's cultural background, because the whole thing that they do is based on what they saw and felt. Culture-based learning (ethnomathematics) is one alternative that can bridge cultures in mathematics. Pannen (Sutama at al, 2013) also said that a strategy of creating a culture based learning environments and learning experiences that integrate culture as part of the learning process. Cultures are integrated into the learning of mathematics in this study is 
the local nature of-context culture Medan, Indonesia. Based on the previously strippedelaboration, the researchers have a hypothesis that through the application of problem-based learning local culture is expected to improve the ability of creative thinking of students, especially high school students in Medan, Indonesia.

\section{METHODS}

\section{Types of research}

This type of research is quasi-experimental (quasi-experiment). The independent variables in this research are problem-based learning local culture (PBL-Local Culture) and classical learning. The dependent variable is students' creative thinking ability. While the control variables in this study were gender students, who are classified in two categories, namely: women and men and the students' prior mathematics ability were classified into three categories: high, medium and low. This design research is pretest-posttest control (pre-posttest control group design) and selected in two groups, there are an experimental class and a control class.

\section{Research Procedure}

This study used a quasi-experimental research design (quasi-experiment) with the type of pretest-posttest control group. This study uses two classes, namely research, experimental class (who got treatment PBL-Local Culture) and the control class (who does not receive the treatment. Research began by preparing a research instrument consisting of questions related to students' creative thinking abilities. Each research instrument has the elements and indicators needed in the ability to think creatively, including fluency, flexibility, originality, and elaboration. In addition, each research instrument also reflects daily problems that contain elements of local culture. The next stage is to conduct a research instrument testing test conducted on a group of students who are not a research sample group. The instrument testing consists of content validity and construct validity tests, and reliability tests. After the research instrument shows the value of validity and reliability, the researcher can use the research instrument to be used in research in the field.

The next stage is to carry out the learning process using a problem-based learning model based on local culture. At this stage, groups of students in each learning class (experimental class and control class) are divided into several groups of students randomly based on gender categories and the level of prior mathematics abilities of students. This is done so that this study can provide significant and objective results on the controlling factors of this study, namely the gender difference factor and the students' prior mathematics ability factor. The learning process lasts for 8 face-to-face meetings and begins with the provision of pre-test and ends with the provision of post-test related to mathematics material. During the learning process, the researcher uses the stages of learning with a problem-based learning model, which is preceded by giving daily problems that contain elements of local culture, grouping students into groups, giving students the opportunity to investigate the given problem, making a percentage of results of the investigation, reviewing the results of the presentation to conclude the results of the discussion. The learning process emphasizes the student-centered approach and minimizes the role of the teacher. The teacher only acts as a facilitator and referee in the process of discussion and problem solving. The teacher also provides assistance by strengthening scaffolding to students so students can use prior knowledge to solve the problem. 


\section{Data Collection Techniques}

Data was collected through the provision of test descriptions consisting of pre-test and posttest. Validity and reliability testing is done using the Product-Moment Correlations test and the Cronbach-Alpha test. The next step is to carry out the prerequisite test, namely the data normality test using the Kolmogorov-Smirnov test and the data homogeneity test using the Levene Test. This test is carried out in order to find out what hypothesis testing is appropriately used in the data.

\section{Data analysis technique}

Data were analyzed using statistical tests Two-Way ANOVA. All statistical tests using significant values below 0,05. Software used for the whole test the SPSS 25 . The results of the analysis of research data will be interpreted and used as a guide in determining which statistical hypotheses are accepted.

\section{RESULTS AND DISCUSSION}

Table 1 provides general information about the students' creative thinking ability following the factors involved. Overall accordance with the gender category of students, students' prior mathematics ability, the experimental group (treated by using PBL-Local Culture) get better results than the control group (treatment using conventional learning). From the results of data processing using Kolmogorov-Smirnov Test and Levene Test showed that samples taken from a normally distributed population and has a homogeneous variance.

Table 1. Description of Students' Creative Thinking Ability

\begin{tabular}{lcccccc}
\hline & $\mathbf{N}$ & Min & Max & $\overline{\boldsymbol{X}}$ & SD & Variance \\
\hline Pretest_Experiment & 30 & 6.0 & 12.0 & 8.43 & 1.66 & 2.77 \\
Posttest_Experiment & 30 & 13.0 & 19.0 & 15.47 & 1.65 & 2.72 \\
Pretest_Control & 30 & 5.5 & 10.5 & 8.38 & 1.26 & 1.58 \\
Pretest_Control & 30 & 11.5 & 18.0 & 14.02 & 1.68 & 2.82 \\
Valid N (listwise) & 30 & & & & & \\
\hline
\end{tabular}

Table 2, Table 3 and Table 4 presents the data description of students' creative thinking ability based on the scores of $\mathrm{N}$-Gain seen from learning groups, gender groups and groups of students' prior mathematics ability.

Table 2. Description of Students' Creative Thinking Ability Based on N-Gain Each Learning

\begin{tabular}{lccccc}
\hline \multirow{2}{*}{ Group } & \multicolumn{5}{c}{ N-Gain Score } \\
\cline { 2 - 6 } & $x_{\min }$ & $x_{\text {maks }}$ & $\bar{x}$ & $S D$ & Category \\
\hline Experiment & 0,25 & 0.75 & 0,55 & 0,11 & Medium \\
Control & 0,24 & 0,74 & 0,47 & 0,14 & Medium \\
\hline
\end{tabular}

Based on table 2 above, we know that both the minimum N-Gain value, the maximum value and the average value in the two learning classes are different. Students who are taught by using the model of problem-based learning based on local culture (PBL-LC) get higher grades compared to the value of students taught using the classical learning model. This is due to the influence of using the new learning model for students, so students feel enthusiastic and enthusiastic in following the learning process. The group of students in the experimental class also has high self-confidence so that they are enthusiastic in solving the given problem. On the other hand, if you pay attention to the standard deviation values obtained by the two learning classes are also different, but this can be interpreted that the values obtained by the two learning 
classes spread normally, and no student has a significantly different value from other students. Based on this, the two classes obtained the medium category at the standard deviation value.

Table 3. Description of Students' Creative Thinking Ability Based on Gender Category

\begin{tabular}{lcccccc}
\hline \multirow{2}{*}{ Gender } & \multicolumn{3}{c}{ PBL-Local Culture } & \multicolumn{3}{c}{ Classical Learning } \\
\cline { 2 - 7 } & $\mathbf{N}$ & $\overline{\boldsymbol{X}}$ & SD & $\mathbf{N}$ & $\overline{\boldsymbol{X}}$ & SD \\
\hline Male & 14 & 0,56 & 0,10 & 16 & 0,50 & 0,14 \\
Female & 16 & 0,53 & 0,12 & 14 & 0,49 & 0,13 \\
\hline
\end{tabular}

The results presented in table 3 specifically explain that there are differences between the average N-Gain scores of groups of students by sex category. There is a difference that is not too far between students with male gender and students with female gender. Based on table 3 above, practically it can be seen that differences in gender of students do not affect the results of increasing students' creative thinking abilities. In addition, the number of students with male and female genders that are not too much different can also be a reason why the average $\mathrm{N}$ Gain value of the two groups of students is also not significantly different.

Table 4. Description of Students' creative Learning Based on Students' Prior Mathematics Ability

\begin{tabular}{lcccccc}
\hline \multirow{2}{*}{$\begin{array}{c}\text { Level of Prior } \\
\text { Mathematics Ability }\end{array}$} & \multicolumn{3}{c}{ PBL-Local Culture } & \multicolumn{3}{c}{ Classical Learning } \\
\cline { 2 - 7 } & $\mathbf{N}$ & $\overline{\boldsymbol{X}}$ & $\mathbf{N}$ & $\overline{\boldsymbol{X}}$ & $\mathbf{N}$ & $\overline{\boldsymbol{X}}$ \\
\hline High & 9 & 0,59 & 0,09 & 7 & 0,43 & 0,10 \\
Moderate & 15 & 0,60 & 0,11 & 16 & 0,53 & 0,13 \\
Low & 6 & 0,49 & 0.07 & 7 & 0,51 & 0,15 \\
\hline
\end{tabular}

Other results can also be seen in table 4 above, namely the students 'prior mathematics ability factor also has no practical effect on increasing students' creative thinking abilities. Table 4 shows that the scores held by groups of students at high, moderate, and low levels (prior mathematics ability level) do not have a significant difference. This is also due to the fact that the students' initial knowledge is not that students can understand teaching material and can solve everyday problems properly and appropriately. Early knowledge is indeed needed in learning mathematical material, because mathematics itself is a hierarchical science. However, it is not a major supporting factor in increasing students' creative thinking abilities. Based on the explanation above, it can be concluded that practically gender and students 'prior mathematics abilities have no role in increasing students' creative thinking abilities. Furthermore, researchers feel the need for further statistical tests on the results of the calculation of research data obtained. Researchers Prepare research hypotheses consisting of three hypotheses, including:

Hypothesis 1: There is an increased of students' creative thinking ability which taught using problem-based learning local culture (PBL-Local Culture).

Hypothesis 2: There is no interaction between the increased of creative thinking ability with students are taught by using problem-based learning local culture (PBL-Culture Local) and students' gender.

Hypothesis 3: There is no interaction between the increased of creative thinking ability students are taught by using problem-based learning local culture (PBL-Local Culture) and students' prior mathematics ability. 
The test result of two way-ANOVA and N-Gain of students' creative thinking ability of experiment and control group and presented in Table 5.

Table 5. Test Result of Interaction between Students' Creative Thinking Ability and Students' Gender Using Two-Way ANOVA

\begin{tabular}{|c|c|c|c|c|c|}
\hline \multicolumn{6}{|c|}{ Tests of Between-Subjects Effects } \\
\hline \multicolumn{6}{|c|}{ Dependent Variable: NGain_Students'_Creative_Thinking_Ability } \\
\hline Source & Type III Sum of Squares & df & Mean Square & $\mathbf{F}$ & Sig. \\
\hline Corrected Model & $.151^{\mathrm{a}}$ & 3 & .050 & 3.246 & .029 \\
\hline Intercept & 15.503 & 1 & 15.503 & 999.044 & .000 \\
\hline Learning_Groups & 126 & 1 & .126 & 8.100 & .006 \\
\hline Student_Gender & .025 & 1 & .025 & 1.627 & .207 \\
\hline Learning_Group * & .007 & 1 & .007 & .455 & .503 \\
\hline \multicolumn{6}{|l|}{ Student_Gender } \\
\hline Error & .869 & 56 & .016 & & \\
\hline Total & 16.636 & 60 & & & \\
\hline Corrected Total & 1.020 & 59 & & & \\
\hline a. $\mathrm{R}$ Squared $=, 116$ & djusted R Squared $=, 103$ ) & & & & \\
\hline
\end{tabular}

Based on Table 5 shows that the factors for learning group, the value of $\mathrm{F}$ count equal to 8,100 and the significant value of 0.006 . Because the value is significantly smaller than the value of the significant level of 0.05 , then $\mathrm{H}_{0}$ rejected, and $\mathrm{H}_{1}$ accepted. Thus, it can be concluded that the increase in students' creative thinking ability who received problem-based learning local culture (PBL-Local Culture) higher than the students' creative thinking ability who received conventional learning.

From Table 5 also shows that the gender factors for students and group learning, the value of $F$ count equal to 0,455 and the significant value of 0.503 . Based on the result, we found that the significant value is higher than the value of the significant level of 0.05 , then $\mathrm{H}_{0}$ rejected, and $\mathrm{H}_{1}$ accepted. Thus, it can be concluded that there was no significant interaction between gender and learning to increase students' creative thinking ability acceptable. It shows that the average gain of students' creative thinking ability with students' gender (male and female) who are taught by local cultural problem-based learning (PBL-Local Culture) did not differ significantly with students taught by classical teaching. The interaction test chart can be seen in Figure 1 below:

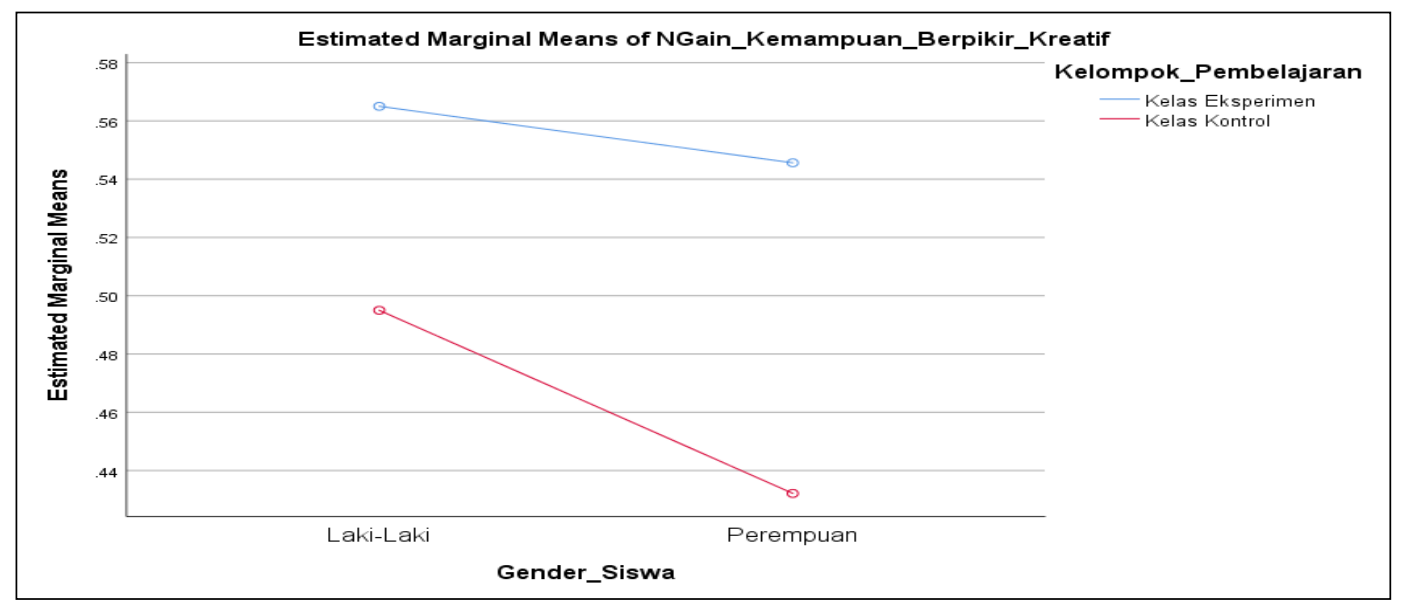

Figure 1. Interaction between students' creative thinking ability and students' gender 
Another factor to be tested involvement to increase creative thinking ability is the capability of students' prior mathematics ability. Based on test results analysis using Two-Way ANOVA on the interaction factor of students' prior mathematics ability can be seen in Table 6 below:

Table 6. Test Result of Interaction between Students' Creative Thinking Ability and Students' Prior Mathematics Ability Using Two-Way ANOVA

\begin{tabular}{lccccc}
\hline \multicolumn{5}{c}{ Tests of Between-Subjects Effects } \\
\hline \multicolumn{5}{c}{ Dependent Variable: NGain_Students'Creative_Thinking_Ability } \\
\hline \multicolumn{1}{c}{ Source } & Type III Sum of Squares & df & Mean Square & F & Sig. \\
\hline Corrected Model & $.166^{\mathrm{a}}$ & 5 & .033 & 2.097 & .080 \\
Intercept & 13.248 & 1 & 13.248 & 837.475 & .000 \\
Learning_Groups & .095 & 1 & .095 & 5.984 & .018 \\
Student_Prior_Math_ & .007 & 2 & .004 & .229 & .796 \\
Ability & & & & & \\
Learning_Group * & .040 & 2 & .020 & 1.279 & .287 \\
Student_Prior_Math_ & & & & & \\
Ability & .854 & 54 & .016 & & \\
Error & 16.636 & 60 & & & \\
Total & 1.020 & 59 & & & \\
Corrected Total & & & & & \\
a. R Squared =,116 (Adjusted R Squared $=.085)$ &
\end{tabular}

From Table 6 also shows that the factors for learning group and prior knowledge of students, the value of $\mathrm{F}$ count equal to 1,279 and the significant value of 0,287 . Based on the result, we found that the significant value is higher than the value of the significant level of 0.05 , then $\mathrm{H}_{0}$ rejected and $\mathrm{H}_{1}$ accepted. Thus, it can be concluded that there was no significant interaction between students' prior mathematics learning and students' creative thinking ability can be accepted. It shows that the average gain of students' creative thinking ability with prior knowledge of students (high, medium, low) taught by local cultural problem-based learning (PBL-Local Culture) did not difference significantly with students taught by classicall teaching. The interaction test chart can be seen in Figure 2 below:

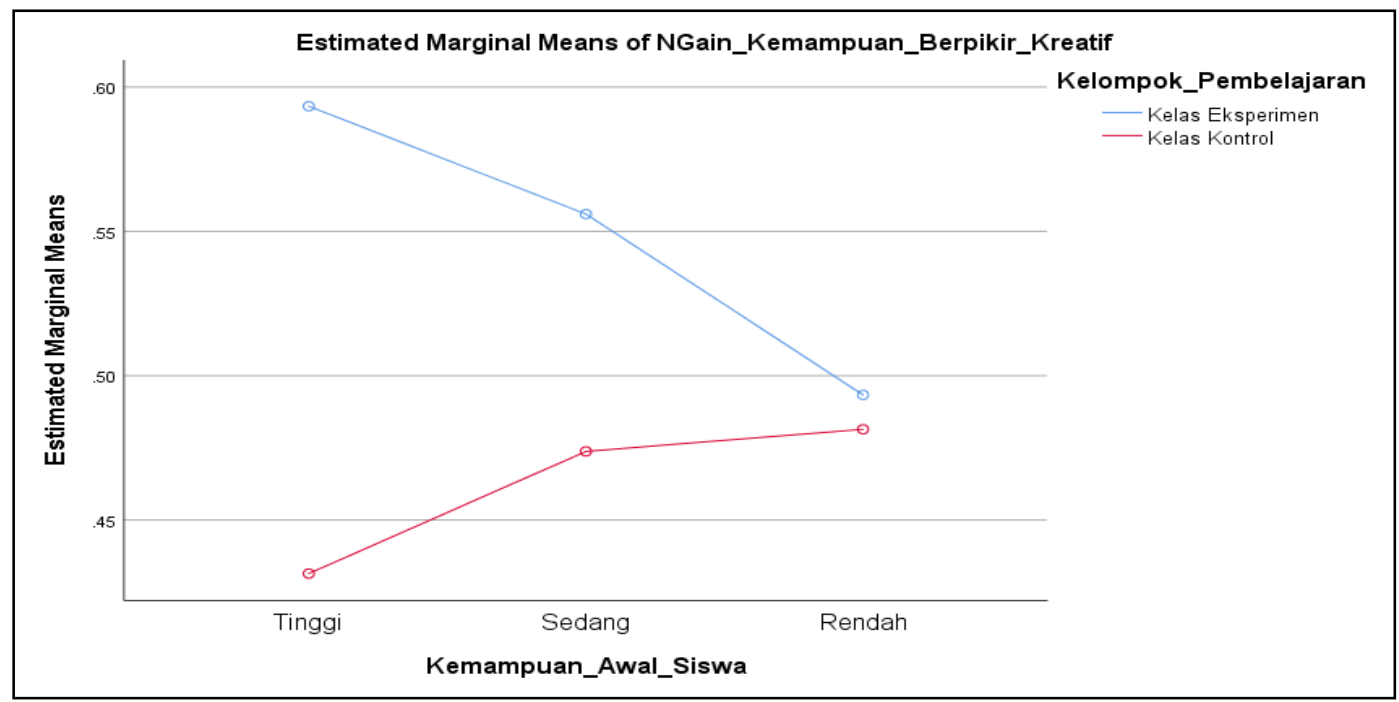

Figure 2. Interaction between students' creative thinking ability and students' prior mathematics ability 
Based on the explanation above, it can be concluded that students who are taught with a problem based learning model locally (PBL-Local Culture) have more influence in improving students' creative thinking abilities (based on the average scores obtained by students in this class are higher than the average score average obtained in conventional classes). So there is no interaction between gender learning by students and students 'initial ability to improve students' creative thinking abilities. Further tests conducted further analysis of the capability of beginning students is done by using the Post-Hoc LSD test that can be seen in Table 7 below:

Table 7. Result of Post-Hoc LSD Advanced Test Calculation

\section{Multiple Comparisons}

Dependent Variable: N-Gain the Creative Thinking Ability

\begin{tabular}{|c|c|c|c|c|c|c|}
\hline \multicolumn{7}{|l|}{ LSD } \\
\hline \multirow{2}{*}{$\begin{array}{c}\text { (I) } \\
\text { Student_Additional } \\
\text { Ability }\end{array}$} & \multirow{2}{*}{$\begin{array}{c}\text { (J) Student_Additional } \\
\text { Ability }\end{array}$} & \multirow{2}{*}{$\begin{array}{l}\text { Mean } \\
\text { Differe } \\
\text { nce (I- } \\
\text { J) }\end{array}$} & \multirow[t]{2}{*}{ Std. Error } & \multirow[t]{2}{*}{ Sig. } & \multicolumn{2}{|c|}{$\begin{array}{c}95 \% \\
\text { Confidence } \\
\text { Interval }\end{array}$} \\
\hline & & & & & $\begin{array}{l}\text { Lower } \\
\text { Bound }\end{array}$ & $\begin{array}{l}\text { Upper } \\
\text { Bound }\end{array}$ \\
\hline \multirow[t]{2}{*}{ High } & Moderate & .0090 & .03872 & .818 & -.0687 & .0866 \\
\hline & Low & .0356 & .04696 & .452 & -.0586 & .1297 \\
\hline \multirow{2}{*}{ Moderate } & High & -.0090 & .03872 & .818 & -.0866 & .0687 \\
\hline & Low & .0266 & .04156 & .524 & -.0567 & .1099 \\
\hline \multirow[t]{2}{*}{ Low } & High & -.0356 & .04696 & .452 & -.1297 & .0586 \\
\hline & Moderate & -.0266 & .04156 & .524 & -.1099 & .0567 \\
\hline
\end{tabular}

Based on observed means.

The error term is Mean Square (Error) $=.016$.

According to table 7 above, it can be seen that there is no difference N-Gain of creative thinking abilities of students on any prior knowledge of students (high, medium and low). It can be concluded that the initial ability of students did not give further effect in improving the ability of creative thinking high school students.

The accordance with the statement of Mellin-Olsen (Ramadhani \& Narpila, 2018) namely: "Increasingly acknowledged that the cognitive level of student response in mathematics is determined not by the 'ability' of the student, but the skill with the which the teacher can engage the student in mathematical 'activity'. From these opinions, it can be concluded that the cognitive level of students in mathematics is not determined by the ability of the students, but the skills of teachers in engaging students in mathematics learning activities. Additionally, due to the advantage of problem-based learning that is supported by the theory of constructivism and constructionism. The constructivist theory is supported by the theory (Perkins, Piaget and Vygotsky) explains that individuals can build knowledge through their neighborhood. Thus, by way of investigation, conversation, or activities (Grant, 2002).

Similar results were obtained by previous researchers, which showed that students who used problem-based learning were higher than the final test results of students using conventional teaching (Ajai et al, 2013). The results obtained state that students' mathematical problem-solving abilities to use problem-based learning are higher than students who use direct learning. Problem-based learning (PBL) also gives the effect of increased cognitive abilities of students. Furthermore, he stated that the application of problem-based learning (PBL) is very useful in improving student performance in the classroom. They also found that through the application of PBL, students learn a new experience, namely real resolve issues close to the 
everyday lives of these students (Bahri et al, 2018), Students can analyze the problem and apply deductive and inductive processes to understand the problem and find a solution (Tarmizi \& Bayat, 2010), PBL is also a significant learning model, practical and relevant in everyday problems of students (Albanese \& Mitchell, 1993), Through the application of PBM, students feel the sensation of learning enjoyable, stimulating, and easily applied in solving real problems (De Vries et al, 1989; Wijnen et al, 2017),

The application of the model student-centred learning (one of which PBL) integrated with the local culture identifies that mathematical ability of students in the process of solving real problems can develop. Thus, environmental factors such as the local cultural context can provide a positive impact on the development of students' mathematical abilities. As has been explained previously that student-centred learning, one of the local culture-based on learning and teaching support the meaningful learning process and improve students' ability to think creatively. This is the distinguishing factor between this research and other studies. Research that only uses non-routine problems of students in problem-based learning students still provides difficulties for students to apply them in everyday life. This is because the non-routine problem is not close to the environment of student life and is not a problem that is often encountered by students. The use of non-routine problems so far has only focused on nonroutine problems that are abstract in nature (Hendriana \& Fadhillah, 2019; Ratnaningsih, 2017; Saptenno et al., 2019; Sihaloho et al., 2017). This is the main factor why this research focuses on the use of non-routine problems that are near the environment of student life through the concept of applying local culture. The application of the concept of local culture provides students with a way to find their version of a non-routine problem solving model, and this has an effect on increasing students' creative thinking abilities (Rahmawati et al., 2019).

\section{CONCLUSIONS}

To improve students' creative thinking ability in the learning process in school requires a high commitment between students and teachers. Another thing that is very important in increasing students' creative thinking abilities is a learning model that implements the application of active learning model, it is problem-based learning model. Problem-based learning model invites students to contributed in the learning process, as in group investigation. Investigation group aims to create a meaningful learning atmosphere. Collaboration between students, teachers and appropriate learning model can create an atmosphere conducive to learning can improve students 'mathematical abilities, one of which is the students' creative thinking ability. In addition to the students' cognitive factors that may evolve, affective factor students can also develop well. In this study, we can concluded that problem based on local culture can use in mathematics learning. It means that, students' can solve their daily non-routine problem with their way and can use their local culture to solve that problem. The usage of local culture concepts in mathematics problem can assists students to know their culture and get used it to their problem life. This study was found that gender gap and prior knowledge cannot be used as main factor on improving students' academic skill. Students' creative thinking ability can being improve because of the contribution of learning model, and also joyful learning environment. But, this study still have limitation, especially in sampling amounts. We suggest for the next researcher could developed this research in large sampling. 


\section{AUTHOR CONTRIBUTIONS STATEMENT}

$\mathrm{RR}$ and FF as the main drafter in this study. The study was designed, conceptualized and carried out by them. FL and AMP had been an integral part of the whole process from brainstorming to writing her input has always been important. She played an important role in data collection and analysis.

\section{REFERENCES}

Abdurrahman, Romli, S., Distrik, I. W., Herlina, K., Umam, R., Ramadhani, R., \& Sumarni, S. (2020). Development and validation of open ended based on worksheet for growing higher level thinking skills of students. European Journal of Educational Research, 9(2), $445-455$.

Ajai, J. T., Imoko, B. I., \& O'kwo, E. I. (2013). Comparison of the learning effectiveness of problem-based learning (PBL) and conventional method of teaching algebra. Journal of Education and Practice , 4(1), 113-136.

Albanese, M. A., \& Mitchell, S. (1993). Problem-based learning. Academic Medicine, 68(1), $52-81$.

Azis, S. A. (2012). Pengembangan kemampuan berpikir kreatif siswa dalam pembelajaran matematika dengan pendekatan pendidikan matematika realistik Indonesia (PMRI). AlBidayah, 4(1), 37-48.

Bahri, A., Putriana, D., \& Idris, I. S. (2018). Peran PBL dalam meningkatkan keterampilan pemecahan masalah biologi. Jurnal Sainsmat, 7(2), 114-124.

De Vries, M. W., Schmidt, H. G., \& de Graaff, E. (1989). Dutch Comparison: Cognitive and Motivational Effects of Problem-Based Learning on Medical Students. New Directions for Medical Education, Aalborg University.

Gordah, E., \& Astuti, R. (2013). Meningkatkan kemampuan komunikasi matematis siswa melalui pengembangan bahan ajar geometri dasar berbasis model recipcoral teaching di STKIP PGRI Pontianak. Prosiding Dalam Seminar Nasional Matematika Dan Pendidikan Matematika.

Grant, M. M. (2002). Getting a grip on project-based learning: Theory, cases and recommendations. Meridian: A Middle School Computer Technologies Journal, (1), 83.

Hendriana, H., \& Fadhillah, F. M. (2019). The students' mathematical creative thinking ability of junior high school through problem-solving approach. Infinity Journal, 8(1), 11.

Munandar, U. (2009). Pengembangan Kreativitas Anak Berbakat. Jakarta: Rineka Cipta.

Nur'aeni. (2008). Ada apa dengan keativitas? ISLAMADINA, 7(3), 74-84.

Rahman, R. (2012). Hubungan antara self-concept terhadap matematika dengan kemampuan berpikir kreatif matematika siswa. Infinity. Infinity, 1(1), 19-30.

Rahmawati, R., Lestari, F., \& Umam, R. (2019). Analysis of the effectiveness of learning in the use of learning modules against student learning outcomes. Desimal: Jurnal Matematika, 2(3), 233-240.

Ramadhani, R. (2016). Pengembangan perangkat pembelajaran matematika yang berorientasi pada model problem based learning. KREANO, Jurnal Matematika Kreatif-Inovatif, 7(2), 116-122. 
Ramadhani, R. (2018). The enhancement of mathematical problem solving ability and selfconfidence of students through problem based learning. Jurnal Riset Pendidikan Matematika, 5(1), 127-134.

Ramadhani, R., \& Narpila, S. D. (2018). Problem based learning method with geogebra in mathematical learning. International Journal of Engineering and Technology(UAE), 7(3.2 Special Issue 2).

Ratnaningsih, N. (2017). The analysis of mathematical creative thinking skills and self-efficacy of high students built through implementation of problem based learning and discovery learning. JPMI (Jurnal Pendidikan Matematika Indonesia), 2(2), 42.

Saptenno, A. E., Tuaputty, H., Rumahlatu, D. E., \& Papilaya, P. M. (2019). The improvement of learning motivation and creative thinking skills of senior high school students through modified problem based learning model. Journal for the Education of Gifted Young Scientists, 7(4), 1173-1192.

Sihaloho, R. R., Sahyar, S., \& Ginting, E. M. (2017). The effect of problem based learning (PBL) model toward student's creative thinking and problem solving ability in senior high school. IOSR Journal of Research \& Method in Education (IOSRJRME), 07(04), 11-18.

Sutama, M., Mulyaningsih, S. S., \& Lasmawan, W. (2013). Solving the problem of the influence of model -based local culture of achievement motivation and learning achievement IPS. E-Journal Ganesha Education University Graduate Program, 3.

Tandailing. (2013). Pengembangan pembelajaran matematika sekolah dengan pendekatan etnomatematika berbasis budaya lokal sebagai upaya untuk meningkatkan kualitas pembelajaran matematika di sekolah. Prosiding Seminar Nasional Matematika Dan Pendidikan Matematika-FMIPA UNY.

Tarmizi, R. A., \& Bayat, S. (2010). Effects of problem-based learning approach in learning of statistics among university students. Procedia - Social and Behavioral Sciences.

Van den Heuvel-Panhuizen, M. (1996). Assesment and realistic mathematics education. Netherlands: Netherlands: CD-B Press Utrecht University.

Wijnen, M., Loyens, S. M. M., Smeets, G., Kroeze, M., \& van der Molen, H. (2017). Comparing problem-based learning students to students in a lecture-based curriculum: learning strategies and the relation with self-study time. European Journal of Psychology of Education, 32(3), 431-447. 
Ramadhani, R., Farid, F., Lestari, F., \& Machmud, A. 